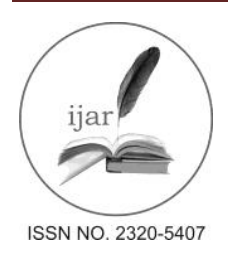

Journal homepage: http://www.journalijar.com

Journal DOI: $\underline{\text { 10.21474/IJAR01 }}$

INTERNATIONAL JOURNAL

OF ADVANCED RESEARCH

RESEARCH ARTICLE

\title{
FACTORS AFFECTING JOB SATISFACTION OF BANKS' EMPLOYEES IN SOUTH EAST REGION OF VIETNAM
}

\author{
Nguyen Nguyen Phuong ${ }^{(1)}$, Tran Duc Thang ${ }^{(2)}$ \\ (1) Industrial University of Ho Chi Minh city, Vietnam \\ (2) 175 Military Hospital, Ho Chi Minh city, Vietnam
}

\section{Manuscript Info}

Manuscript History:

Received: 12 February 2016

Final Accepted: 22 March 2016

Published Online: April 2016

Key words:

\begin{abstract}
Job satisfaction, Bank, Employee, South East region, Banks' employees
\end{abstract}

Nguyen Nguyen Phuong.

\begin{abstract}
In the knowledge economy time, when the role of mental labor is getting more and more important, humans become the most critical resource of modern society, a strategic resources, and one of the key factors determining whether a business succeed or not. Possessing and retaining "elite forces" that have good abilities, enthusiasm, and a commitment to be webbed to the business are in fact a great challenge to businesses providing services as it's considered as the input materials, especially those in services fields such as banking, which require grey matter and human resource. The research is conducted to make a significant contribution to the theoretical system, as well as establishing new scale in measuring job satisfaction of banks' employees. Commercial banks could make use of this research result, especially the key elements of job satisfaction of banks' employees, for designing appropriate policies and methods to keep their employees, forming the foundation to advance the business efficiency and competitiveness.
\end{abstract}

\section{Literature review:-}

According to Vroom (1964), employee satisfaction is the state of the employees incentivized by three expected value elements: occupation, working facilities and attraction of labor outcomes. However, Hackman and Oldham (1975) stated that employee satisfaction is a series of experienced and perceived values from the combination of five core job characteristics: Skill variety, task identity, task significance, autonomy and job feedback creating working motivations and high productivity.

Herzberg (1959) and Alderfer (1969) shared an idea about the definition of employee satisfaction that the employee's passion for work or efforts to continue to work expressed through their awareness (positive, negative or both) of different job aspects impacting on them, while Kreitner and Kinicki (2007) said that the job satisfaction partial reflects the attitude toward the job that employees like as well as the satisfaction level in measure scale of factors, payment, promotion, supervision, colleague relationship and other factors they expect.

Smith, Kendall and Hulin (1969) supposed the employee satisfaction can be measured via JDI (Job Descriptive Index), expressed through five following factors: the nature of the work itself, compensations and benefits, attitudes towards supervisors, relations with co-workers, and opportunities for promotion.

Having the same interest in identifying factors affecting employee satisfaction with other authors, Weiss (1967) defined that employee satisfaction is expressed through two groups of satisfaction measuring factors: intrinsic factors and extrinsic factors. Moreover, he provides additional general criteria like working condition, teamwork method, etc. 
In theory of Edwin Locke (1976), he contended that employee satisfaction is reflected through work value of factor measure scale: Job characteristics; Salaries and benefits; Promotions; Productivity recognitions; Working conditions; Colleagues; Supervision; Labor-Union.

Society for Human Resource Management SHRM (2009) believed that employee satisfaction in each period is expressed through the group of the most important satisfaction factors (Job security, benefits, compensation/pay, opportunities to use skills and abilities, work safety); group of various aspects (Career development opportunities, communication between employees and senior management and the work itself, working environment) and the overall satisfaction level of employees.

Mcclelland's Achievement theory (1988) focuses on how to create motivation in work and improve operation process thanks to satisfying people's need for achievement.

Vroom's expectancy theory is applied to satisfy employee needs based on their perception; hence, it is required to have appropriate factor scale established by organizations on the basis of the following characteristics: Efforts to complete jobs, job performance result in the optimal effectiveness, rewards

The famous Herzberg's two-factor theory (1959) presented two aspects affecting job satisfaction level, "Motivation" Factors impact on positive trend, and "Hygiene" Factors impact on negative trend. This theory suggests that Motivation factors leading to job satisfaction affects opposed to Hygiene factors leading to job dissatisfaction of the employees. Motivation factors include: Achievement, Recognition, Responsibility, Work Itself, Promotion, and Growth. Hygiene factors include Working Conditions, Supervision, Salary, Status, Safety, Team Building, Job Characteristics, Company Policies and Administration, Personal Relation.

In brief, there are a numbers of different definitions about employee satisfaction. In general, it is defined as “employees" job satisfaction or dissatisfaction" is considered through various evaluation criteria. Every researcher has his/her own view on employee satisfaction through their studies.

After studying literature review, previous researches, and others factor scales measuring employee satisfaction towards enterprises, the author oriented to select model by the following arguments. The inheritance and development of combining and selecting some theoretical basis and researches on factor scale of the previous researchers; it, however, should suit to the objectives of the research;

Foundation for six factors used in factor scale in research model:

\begin{tabular}{|c|c|c|}
\hline No. & Factor scales & Typical author \\
\hline 1 & Salary and benefits (SB) & $\begin{array}{l}\text { Herzberg (1959); Smith, Kendall và Hulin (1969); Weiss (1967); Edwin } \\
\text { Locke (1976); Keith \& John (2002); SHRM (2009); Kim Dung (2005) }\end{array}$ \\
\hline 2 & Performance assessment (E) & Herzberg (1959); Edwin Locke (1976); Survey SHRM (2009) \\
\hline 3 & Training and promotion $(\mathrm{T})$ & $\begin{array}{l}\text { Smith, Kendall \& Hulin (1969); Weiss (1967); Edwin Locke (1976); } \\
\text { SHRM (2009); Andrew (2002); }\end{array}$ \\
\hline 4 & Job autonomy (TUCHU) & Weiss (1967); Edwin Locke (1976); SHRM (2009) \\
\hline 5 & Job stability (JF) & Herzberg (1959); Survey SHRM (2009); \\
\hline 6 & Working conditions (WE) & Herzberg (1959); Edwin Locke (1976); SHRM (2009) \\
\hline
\end{tabular}

\section{Research method:-}

Qualitative research: Qualitative research is applied through group discussion based on the previous studies and theories to establish and develop variables used in definitions and measure scales, so that the definitions and measure scales systems are defined suiting for characteristics of job satisfaction of organization's staffs. In this step, the questionnaire is formed.

Quantitative research: Quantitative research is carried out by collecting data via interview, questionnaire designed in step 1. This research method is used to evaluate the measure scale, test the theoretical model expressing the relations between factors and employees' satisfaction of some banks located in South East region of Vietnam. The factor measure scale is preliminary tested via Cronbach's Alpha and Factors analysis through SPSS18.0 for windows. The regression analysis is applied to test the research model and research hypothesizes. 
Sample is selected in a convenient way to estimate the sample size $n=171$. Besides, data analysis methods used in the study is the method of linear regression models require large sample size because it is based on a large sample distribution theory (Raykov and Widaman 1995). Thus, the estimated sample size of 171 is appropriate.

\section{Research result:-}

Factor Analysis:-

Table 4.13. KMO and Bartlett's Test

Kaiser-Meyer-Olkin Measure of Sampling Adequacy.

Bartlett's Test of Sphericity

\begin{tabular}{|l|l|}
\hline Approx. Chi-Square & .770 \\
\hline df & 3588.028 \\
\hline Sig. & 496 \\
\hline
\end{tabular}

The KMO value $=0,770>0.5 \Rightarrow>$ Factor analysis is appropriate

Sig $($ Barlett's Test) $=0<0.05=>$ Variables are generally correlated.

There are 6 components affect bank's employee satisfaction (Eigenvalues of 6 components $=2.532>1$ ) and these 6 components account for $68.642 \%$ of variation.

There are 6 factors in research model"

- Group of WE (Working Environment) factors: WE1, WE2, WE3,WE4, WE5, WE6

- Group of E (Evaluation) factors: E1, E2, E3, E4, E5,E6, E7, E8

- $\quad$ Group of T (Training) factor: T1, T2, T3, T4

- Group of SB (Salary \& Benefit) factors: SB1, SB2, SB3, SB4

- Group of JF (Job Suitability) factors: JF1, JF2, JF3, JF4

- Group of M (Motivation) factors: M1, M2, M3, M4

Testing Reliability of factors:-

* Group of JF (Job Suitability) factor:-

Table 4.17. Reliability Statistics

\begin{tabular}{|l|l}
\hline Cronbach's Alpha & N of Items \\
\hline .843 & 4 \\
\hline
\end{tabular}

\begin{tabular}{|l|l|l|l|l|}
\hline Table 4.18. Item-Total Statistics \\
\hline & $\begin{array}{l}\text { Scale Mean if Item } \\
\text { Deleted }\end{array}$ & $\begin{array}{l}\text { Scale Variance if Item } \\
\text { Deleted }\end{array}$ & $\begin{array}{l}\text { Corrected Item-Total } \\
\text { Correlation }\end{array}$ & $\begin{array}{l}\text { Cronbach's Alpha if } \\
\text { Item Deleted }\end{array}$ \\
\hline JF1 & 11.1813 & 5.761 & .670 & .805 \\
\hline JF2 & 11.0819 & 5.805 & .702 & .792 \\
\hline JF3 & 11.2924 & 5.690 & .644 & .816 \\
\hline JF4 & 11.3743 & 5.389 & .701 & .791 \\
\hline
\end{tabular}

Testing JF factors. Following Reliability Statistics table, Cronbach's Alpha $=0,843>0.7$. And Item-Total Statistics table shows that Corrected Item-Total Correlation of variables JF1 $=0.670, \mathrm{JF} 2=0.702, \mathrm{JF} 3=0.644, \mathrm{JF} 4$ $=0.701>0.3$.

Therefore, measurement scale is reliable and statistically significant.

* Group of SB (Salary \& Benefit) factor:-

Table 4.19. Reliability Statistics

Cronbach's Alpha

.837
$\mathrm{N}$ of Items

5 


\begin{tabular}{|l|l|l|l|l|}
\hline Table 4.20. Item-Total Statistics \\
\hline & $\begin{array}{l}\text { Scale Mean if Item } \\
\text { Deleted }\end{array}$ & $\begin{array}{l}\text { Scale Variance if Item } \\
\text { Deleted }\end{array}$ & $\begin{array}{l}\text { Corrected Item-Total } \\
\text { Correlation }\end{array}$ & $\begin{array}{l}\text { Cronbach's Alpha if } \\
\text { Item Deleted }\end{array}$ \\
\hline SB1 & 14.0585 & 6.620 & .667 & .796 \\
\hline SB2 & 14.0936 & 6.732 & .677 & .793 \\
\hline SB3 & 13.9415 & 7.161 & .648 & .803 \\
\hline SB4 & 14.2632 & 6.689 & .574 & .825 \\
\hline SB5 & 14.0526 & 6.709 & .643 & .803 \\
\hline
\end{tabular}

Testing SB factors. Following Reliability Statistics table, Cronbach' s Alpha $=0,837>0.7$. And Item-Total Statistics table shows that Corrected Item-Total Correlation of variables SB1 $=0.667$, SB2 $=0.677$, SB3 $=0.648$, $\mathrm{SB} 4=0.574, \mathrm{SB} 5=0.643>0.3$.

Therefore, measurement scale is reliable and statistically significant.

* Group of E (Evaluation) factor:

Table 4.21. Reliability Statistics

Cronbach's Alpha .883 $\mathrm{N}$ of Items

8

\begin{tabular}{|l|l|l|l|l|}
\hline Table 4.22. Item-Total Statistics \\
\hline & $\begin{array}{l}\text { Scale Mean if Item } \\
\text { Deleted }\end{array}$ & $\begin{array}{l}\text { Scale Variance if Item } \\
\text { Deleted }\end{array}$ & $\begin{array}{l}\text { Corrected Item-Total } \\
\text { Correlation }\end{array}$ & $\begin{array}{l}\text { Cronbach's Alpha if } \\
\text { Item Deleted }\end{array}$ \\
\hline E1 & 24.3647 & 32.411 & .723 & .861 \\
\hline E2 & 24.3294 & 32.329 & .694 & .864 \\
\hline E3 & 24.3294 & 34.317 & .604 & .873 \\
\hline E4 & 24.2353 & 35.885 & .479 & .885 \\
\hline E5 & 24.4059 & 32.527 & .664 & .867 \\
\hline E6 & 24.6353 & 32.683 & .738 & .860 \\
\hline E7 & 24.5176 & 32.050 & .713 & .862 \\
\hline E8 & 24.4824 & 33.884 & .587 & .875 \\
\hline
\end{tabular}

Testing SB factors. Following Reliability Statistics table, Cronbach' s Alpha $=0,883>0.7$. And Item-Total Statistics table shows that Corrected Item-Total Correlation of variables E1 $=0.723, \mathrm{E} 2=0.694, \mathrm{E} 3=0.604, \mathrm{E} 4=$ $0.479, \mathrm{E} 5=0.664, \mathrm{E} 6=0.738, \mathrm{E} 7=0.713, \mathrm{E} 8=0.587$ are more than 0.3 .

Therefore, measurement scale is reliable and statistically significant.

* Group of $\mathbf{T}$ (Training) factor:

Table 4.23. Reliability Statistics

Cronbach's Alpha

.912

$\mathrm{N}$ of Items

5

\begin{tabular}{|l|l|l|l|l|}
\hline Table 4.24. Item-Total Statistics \\
\hline & $\begin{array}{l}\text { Scale Mean if Item } \\
\text { Deleted }\end{array}$ & $\begin{array}{l}\text { Scale Variance if Item } \\
\text { Deleted }\end{array}$ & $\begin{array}{l}\text { Corrected Item-Total } \\
\text { Correlation }\end{array}$ & $\begin{array}{l}\text { Cronbach's Alpha if } \\
\text { Item Deleted }\end{array}$ \\
\hline T1 & 14.5380 & 11.297 & .809 & .885 \\
\hline T2 & 14.6667 & 11.506 & .789 & .889 \\
\hline T3 & 14.6316 & 10.940 & .847 & .876 \\
\hline T4 & 14.5088 & 12.016 & .780 & .892 \\
\hline T5 & 14.8246 & 12.216 & .660 & .915 \\
\hline
\end{tabular}

Testing $\mathrm{T}$ factors. Following Reliability Statistics table, Cronbach's Alpha $=0,912>0.7$. And Item-Total Statistics table shows that Corrected Item-Total Correlation of variables $\mathrm{T} 1=0.089, \mathrm{~T} 2=789, \mathrm{~T} 3=847, \mathrm{~T} 4=$ $0.780, \mathrm{~T} 5=0.660>0.3$.

Therefore, measurement scale is reliable and statistically significant.

* Group of M (Motivation) factors:

Table 4.25. Reliability Statistics

Cronbach's Alpha .838

$\mathrm{N}$ of Items 4 


\begin{tabular}{|l|l|l|l|l|}
\hline Table 4.26. Item-Total Statistics \\
\hline & $\begin{array}{l}\text { Scale Mean if Item } \\
\text { Deleted }\end{array}$ & $\begin{array}{l}\text { Scale Variance if Item } \\
\text { Deleted }\end{array}$ & $\begin{array}{l}\text { Corrected Item-Total } \\
\text { Correlation }\end{array}$ & $\begin{array}{l}\text { Cronbach's Alpha if } \\
\text { Item Deleted }\end{array}$ \\
\hline M1 & 11.4678 & 5.592 & .644 & .807 \\
\hline M2 & 11.3275 & 5.163 & .722 & .772 \\
\hline M3 & 11.5965 & 5.642 & .575 & .836 \\
\hline M4 & 11.7135 & 4.888 & .746 & .760 \\
\hline
\end{tabular}

Testing M factors. Following Reliability Statistics table, Cronbach's Alpha $=0,838>0.7$. And Item-Total Statistics table shows that Corrected Item-Total Correlation of variables M1 $=0.644$, M2 $=0.722$, M3 $=0.575$, M4 $=0.746>0.3$.

Therefore, measurement scale is reliable and statistically significant.

* Group of WE (Working Environment) factors:

Table 4.27. Reliability Statistics

\begin{tabular}{|l|l}
\hline Cronbach's Alpha & N of Items \\
.950 & 6 \\
\hline
\end{tabular}

\begin{tabular}{|l|l|l|l|l|}
\hline Table 4.28. Item-Total Statistics \\
\hline & $\begin{array}{l}\text { Scale Mean if Item } \\
\text { Deleted }\end{array}$ & $\begin{array}{l}\text { Scale Variance if Item } \\
\text { Deleted }\end{array}$ & $\begin{array}{l}\text { Corrected Item-Total } \\
\text { Correlation }\end{array}$ & $\begin{array}{l}\text { Cronbach's Alpha if } \\
\text { Item Deleted }\end{array}$ \\
\hline WE1 & 17.9006 & 19.525 & .787 & .947 \\
\hline WE2 & 17.8012 & 18.854 & .835 & .941 \\
\hline WE3 & 17.9942 & 19.418 & .852 & .939 \\
\hline WE4 & 17.8304 & 18.083 & .925 & .930 \\
\hline WE5 & 17.7135 & 20.088 & .819 & .943 \\
\hline WE6 & 17.8070 & 19.086 & .859 & .938 \\
\hline
\end{tabular}

Testing WE factors. Following Reliability Statistics table, Cronbach's Alpha $=0,950>0.7$. And Item-Total Statistics table shows that Corrected Item-Total Correlation of variables WE1 $=0.787$, WE2 $=0.835$, WE3 $=0.852$, WE4 $=0.925$, WE5 $=0.819$, WE6 $=0.859$ are more than 0.3 .

Therefore, measurement scale is reliable and statistically significant.

Inspection of reliability of general scale

Table 4.29. Reliability Statistics

\begin{tabular}{|l|l|}
\hline Cronbach's Alpha & N of Items \\
\hline .775 & 32 \\
\hline
\end{tabular}

Cronbach's Alpha $=0.775>0.7 \Rightarrow$ The scale is reliable and statistically significantl.

Regression equation:-

- Correlation coefficient of $\mathrm{Y}$ and $\mathrm{JF}=-0.128(\mathrm{Sig}=0.048<0.05)$ and correlation of $\mathrm{Y}$ with $\mathrm{JF}$ is negative, level of correlation is very weak.

- Correlation coefficient between $\mathrm{Y}$ and $\mathrm{SB}=0.221(\mathrm{Sig}=0.002<0.05)$ and correlation of $\mathrm{Y}$ with $\mathrm{SB}$ is positive, level of correlation is average.

- Correlation coefficient of $\mathrm{Y}$ and $\mathrm{T}=0.317$ ( $\mathrm{Sig}=0<0.05$ ) and correlation of $\mathrm{Y}$ with $\mathrm{T}$ is positive, level of correlation is tight.

- Correlation coefficient of $\mathrm{Y}$ and $\mathrm{M}=0.405$ ( $\mathrm{Sig}=0<0.05$ ) and correlation of $\mathrm{Y}$ with $\mathrm{M}$ is positive, level of correlation is tight.

- Correlation coefficient of $\mathrm{Y}$ and $\mathrm{WE}=0.514(\mathrm{Sig}=0<0.05)$ and correlation of $\mathrm{Y}$ with WE is positive, level of correlation is very strong.

\begin{tabular}{|c|c|c|c|c|c|c|c|c|c|c|}
\hline \multicolumn{11}{|c|}{ Table 4.34. Model Summary ${ }^{b}$} \\
\hline \multirow[t]{2}{*}{ Model } & \multirow[t]{2}{*}{$\mathrm{R}$} & \multirow{2}{*}{$\begin{array}{l}\mathrm{R} \\
\text { Square }\end{array}$} & \multirow{2}{*}{$\begin{array}{l}\text { Adjusted R } \\
\text { Square }\end{array}$} & \multirow{2}{*}{$\begin{array}{l}\text { Std. Error of } \\
\text { the Estimate }\end{array}$} & \multicolumn{5}{|c|}{ Change Statistics } & \multirow{2}{*}{$\begin{array}{l}\text { Durbin- } \\
\text { Watson }\end{array}$} \\
\hline & & & & & $\begin{array}{l}\mathrm{R} \text { Square } \\
\text { Change }\end{array}$ & $\begin{array}{l}\mathrm{F} \\
\text { Change }\end{array}$ & df1 & df2 & $\begin{array}{l}\text { Sig. F } \\
\text { Change }\end{array}$ & \\
\hline 1 & $.729^{\mathrm{a}}$ & .531 & .514 & .35210 & .531 & 30.921 & 6 & 164 & .000 & 1.574 \\
\hline \multicolumn{11}{|c|}{ a. Predictors: (Constant), WE, M, E, T, SB, JF } \\
\hline b. Depe & lent Vs & able: $Y$ & & & & & & & & \\
\hline
\end{tabular}


Outcome of survey shows that:

- $\quad$ Adjusted R Square $=0.514$. It means $51.4 \%$ of variation of $\mathrm{Y}$ is caused by the above elements.

- Durbin-Watson Coefficient $=1,574$, ranged from 0 to 4, autocorrelation doesn't occur.

\begin{tabular}{|c|c|c|c|c|c|c|}
\hline \multicolumn{7}{|c|}{ Table 4.35. ANOVA ${ }^{\mathrm{a}}$} \\
\hline \multicolumn{2}{|c|}{ Model } & Sum of Squares & df & Mean Square & $\mathrm{F}$ & Sig. \\
\hline \multirow[t]{3}{*}{1} & Regression & 22.999 & 6 & 3.833 & 30.921 & $.000^{\mathrm{b}}$ \\
\hline & Residual & 20.331 & 164 & .124 & & \\
\hline & Total & 43.331 & 170 & & & \\
\hline \multicolumn{7}{|c|}{ a. Dependent Variable: Y } \\
\hline \multicolumn{7}{|c|}{ b. Predictors: (Constant), WE, M, E, T, SB, JF } \\
\hline
\end{tabular}

The above table of result shows that:

- $\mathrm{F}=30.921$ and $\mathrm{Sig}=0<0.05$.

- $\quad$ Adjusted R Square coefficient is $0.514>0.5$

- $\quad$ Regression ( ESS) = 22.999

- $\quad$ Residual $(\mathrm{RSS})=20.331$

- $\quad$ ESS > RSS

$\Rightarrow$ Hence, regression equation is appropriate to the sample and population.

\begin{tabular}{|c|c|c|c|c|c|c|c|c|c|c|}
\hline \multicolumn{11}{|c|}{ Table 4.37. Coefficients ${ }^{\mathrm{a}}$} \\
\hline \multirow{2}{*}{\multicolumn{2}{|c|}{ Model }} & \multicolumn{2}{|c|}{$\begin{array}{l}\text { Unstandardized } \\
\text { Coefficients }\end{array}$} & $\begin{array}{l}\text { Standardized } \\
\text { Coefficients }\end{array}$ & \multirow[t]{2}{*}{$\mathrm{t}$} & \multirow[t]{2}{*}{ Sig. } & \multicolumn{2}{|c|}{$\begin{array}{l}95.0 \% \text { Confidence } \\
\text { Interval for B }\end{array}$} & \multicolumn{2}{|c|}{$\begin{array}{l}\text { Collinearity } \\
\text { Statistics }\end{array}$} \\
\hline & & $\mathrm{B}$ & $\begin{array}{l}\text { Std. } \\
\text { Error }\end{array}$ & Beta & & & $\begin{array}{l}\text { Lower } \\
\text { Bound }\end{array}$ & $\begin{array}{l}\text { Upper } \\
\text { Bound } \\
\end{array}$ & Tolerance & VIF \\
\hline \multirow[t]{7}{*}{1} & (Constant) & .906 & .305 & & 2.974 & .003 & .304 & 1.508 & & \\
\hline & $\mathrm{JF}$ & -.064 & .036 & -.098 & $-\overline{1.803}$ & .073 & -.134 & .006 & .965 & 1.037 \\
\hline & SB & .109 & .043 & .137 & 2.519 & .013 & .023 & .194 & .965 & 1.037 \\
\hline & $\mathrm{E}$ & .016 & .034 & .025 & .464 & .643 & -.051 & .082 & .964 & 1.038 \\
\hline & $\mathrm{T}$ & .158 & .032 & .264 & 4.902 & .000 & .095 & .222 & .986 & 1.014 \\
\hline & $\mathrm{M}$ & .253 & .036 & .376 & 6.948 & .000 & .181 & .325 & .979 & 1.021 \\
\hline & WE & .285 & .031 & .492 & 9.151 & .000 & .223 & .346 & .992 & 1.009 \\
\hline
\end{tabular}

- $\quad$ Removing JF factor and E factor form regression model (because of Sig > 0.05)

- Sig of Beta of the rest factors are less than 0.05

- $\quad$ Every VIF is less than 10.

So we conclude that autocorrelation among independent variables SB, T, M, WE don't happen and groups of variable are appropriate to linear regression model.

We have linear regression model:

Job Satisfaction $=0.906+0.137 \mathrm{SB}+0.264 \mathrm{~T}+0.376 \mathrm{M}+0.492 \mathrm{WE}$

Thus, the final result is composed of four elements:

Factor "Working environment" have the highest influence $\beta=0.492$. When the Working environment is favorable, the extent of satisfaction will be higher. Hence, the leaders should care about improving working environment and equipping new working equipments for employees as well as repairing, renovating and rebuilding the office to make comfortable working conditions for staffs.

Factor "Motivation" with $\beta=0.376$ is an important factors of any organization, so does in this survey. Within their competence, managers need to assign work, autonomy and self-responsibility to work, encourage employees to more participate in decisions relating to job.

Factor "Training" with $\beta=0.264$ has affected the third after "motivation". The banks should encourage and give staffs chances to promote and develop. There are plans for training, career development for employees and clearly inform employees about requirement for to promote in their job. 
The last element is "Salaries and Benefits" with $\beta=0.137$ when the ad was repeated several times to make sure the ability to receive higher. Salary need to be paid fully and in time. Salary is proportionate to staff's performance and salary is adequate to the nature of work and employee's effort. Encouraging employees by using unexpected bonus, regular bonus when employees complete work well. There is plan to improve salary for employees to ensure their life because prices of goods are always increasing more than salary and ensuring a reasonable levels of income between the different departments, different salaries.

The meaning of linear equations could be expressed as following: if WE increases by 1 unit, Job satisfaction (of banks' employees) increases by 0.492 unit with the condition that the following factors are similar. Based on these results, we calculate and determine the impact of each factor that affects job satisfaction of banks' employees in South East region of Viet Nam, in order to design appropriate policies and methods to keep their employees and boost their loyalty to the organizations.

Exploratory Factor Analysis (EFA) reduced the number of observed variables and divided them into four components representing for factors impacting on job satisfaction of staffs of banks in South East region of Vietnam.

Linear regression analysis was implemented to give us linear regression equation as well as level of impact of factors on satisfaction of staffs. Result of regression analysis shows that there are 4 factors strongly impacting on satisfaction of staffs of banks in South East region of Vietnam, including "Working Environment" factor - the most important factor; "Motivation" factor; "Training" factor; and the last is "Salary \& Benefit" factor.

\section{Conclusion:-}

The international and domestic economic declines in the past years have been considered as hardship that the banking and finance sector endures. Vietnamese banking system in general are facing various pressures like expanding network, improving technology, adding more services and the fluctuating in currency market, to name a few. To successfully deal with the variation of the challenging market, banks have constantly been innovating products, technologies, network system, particularly training and developing human resource, which could be considered as the highest priority of businesses in general and banks in specific. Nonetheless, current labor market state proves that, along with the rapid appearance and growth of commercial banks, joint venture banks as well as branches of foreign banks, the demand for banking labor, especially high-quality is vast. These days, a tacit and cutthroat competition for the human resource is happening among banks. To successfully go ahead of this competition, banks are required to enhance the labor resource management efficiency, especially increase the employee satisfaction towards the businesses. They must have appropriate policies and methods based on the research result to keep their employees, create the sense of attachment and contribution, forming the foundation to advance the business efficiency and competitiveness, which are actually really urgent.

\section{References:-}

1 Herzberg, F. (1968), “One more time: how do you motivate employees?”, Harvard Business Review, vol. 46, iss.1, pp. $55-62$.

2 Kreitner, R., Kinicki, A. (2001), Organizational Behavior. (5th ed.) New York: Mc Graw -Hill, pp. 548-571.

3 Locke, E. A. (1976). The nature and causes of job satisfaction. In M. D. Dunnette (Ed.), Handbook of Industrial and Organizational Psychology, Chicago: Rand McNally, 1297-1349.

4 Raykov, T. \& Widaman, K. F. (1995). Issues in applied structural equation modeling research. Structural Equation Modeling, 2(4), 289-31

5 Smith, P. C. , Kendall, L. M., and Hulin, C. L. (1969), The Measurement of Satisfaction in Work and Retirement, Chicago: Rand McNally.

6 Society for Human Resource Management SHRM (2009), Job Satisfaction Survey

7 Trần Kim Dung (2005), "Nhu cầu, sự thỏa mãn của nhân viên và mức độ gắn kết với tổ chức". B2004-22-67, đề tài nghiên cứu khoa học cấp bộ, Trường Đại học Kinh tế TP.HCM

8 Weiss, D. J. , Dawis, R. V. England, G. W. and Lofquist, L. H. (1967), Manual for the Minnesota Satisfaction Questionnaire. Vol. 22, Minnesota Studies in Vocational Rehabilitation, Minneapolis: University of Minnesota, Industrial Relations Center. 